\title{
DAMPAK PENGEMBANGAN PARIWISATA TERHADAP KESEJAHTERAAN MASYARAKAT DI SUNGAI BATU SEI GOHONG KOTA PALANGKA RAYA
}

\author{
Aston Pakpahan \\ Fakultas Ekonomi dan Bisnis Universitas Palangka Raya \\ (email: pakpahanaston21@gmail.com) \\ Alfrid Sentosa \\ Fakultas IImu Sosial dan IImu Politik Universitas PGRI Palangka Raya \\ (email: afrael09@gmail.com)
}

\begin{abstract}
Abstrak
Penelitian ini bertujuan untuk mengetahui apakah dengan adanya pengembangan pariwisata Sungai Batu Sei Gohong Kota Palangka Raya memberikan dampak terhadap kesejahteraan masyarakat disekitar objek wisata. Penelitian ini bersifat deskriptif kualitatif. Sumber data yang digunakan adalah data primer dan data sekunder.Dengan menggunakan metode pengumpulan data yaitu observasi, wawancara, dan dokumentasi.

Hasil penelitian adalah Pengembangan pariwisata Sungai Batu Sei Gohong Kota Palangka Raya memberikan dampak terhadap kesejahteraan masyarakat Sei Gohong yang berada di sekitar objek wisata. Dampak yang signifikan yang dirasakan oleh masyarakat Sei Gohong adalah terbukanya peluang usaha, peluang usaha tersebut terdiri dari usaha kuliner, usaha penginapan, toko cendera mata, toko kelontong, jasa sewa perlengkapan renang.Pendapatan yang diterima oleh masyarakat dari hasil usaha yang dijalankan tersebut dapat mencukupi kebutuhan keluarga, biaya pendidikan dan biaya kesehatan.
\end{abstract}

\section{Kata Kunci: Pengembangan Pariwisata, Kesejahteraan Masyarakat, Sei Gohong}

\section{Pendahuluan}

Perkembangan sektor pariwisata begitu pesat saat ini, menjadikan pariwisata sebagai salah satu sektor unggulan dalam perekonomian nasional. Dengan banyaknya rute-rute penerbangan, destinasi wisata baru, serta meningkatnya akomodasi yang membuktikan bahwa pariwisata sangat berpotensi dalam meningkatkan perekonomian suatu negara. Pariwisata akan memberikan banyak pemasukan bagi daerah yang sadar akan potensinya terhadap sektor pariwisata. Adanya otonomi daerah menjadikan masing-masing daerah berupaya menggali sebesar-besarnya potensi daerahnya.

Pariwisata dapat didefinisikan sebagai keseluruhan jaringan dan gejalagejala yang berkaitan dengan tinggalnya 
orang asing di suatu tempat, dengan syarat bahwa mereka tidak tinggal disitu untuk melakukan pekerjaan yang penting yang memberikan keuntungan yang bersifat permanen maupun sementara. Pariwisata merupakan bagian dari budaya suatu masyarakat yang berkaitan dengan cara penggunaan waktu luang atau waktu libur yang dimiliki seseorang. Selain itu juga pariwisata atau rekreasi telah menjadi kebutuhan hidup masyarakat saat ini

Destinasi pariwisata perlu dikembangkan, terlebih lagi bagi negara sedang berkembang seperti Indonesia. Ada berbagai keuntungan yang dapat diraih, antara lain: terbukanya lapangan pekerjaan, peningkatan kesejahteraan masyarakat di sekitar destinasi pariwisata, meningkatkan nilai/citra suatu wilayah geografis, termasuk yang miskin akan sumber daya ekonomi. Bagi negara sedang berkembang di Indonesia, industri pariwisata dapat dikatakan merupakan media pembangunan ekonomi yang tidak memerlukan investasi terlalu besar. Daya tarik wisata yang merupakan salah satu modal utama untuk pengembangan kepariwisataan, sudah tersedia.

Kepariwisataan sebagian dari pembangunan ekonomi mempunyai tujuan untuk memperluas dan memeratakan kesempatan berusaha, lapangan kerja dan kesejahteraan masyarakat, yang dimaksud kesejahteraan adalah sebuah kondisi dimana seorang dapat memenuhi kebutuhan pokok, baik itu kebutuhan akan makanan, pakaian, tempat tinggal, air minum yang bersih serta kesempatan untuk melanjutkan pendidikan dan memiliki pekerjaan memadai yang menunjang kualitas hidupnya sehingga bebas dari kemiskinan, kebodohan, ketakutan, atau kekhawatiran sehingga hidupnya aman tentram, baik lahir maupun batin.
Desa Wisata Sei (Sungai) Gohong terletak di Kecamatan Bukit Batu, Kota Palangka Raya, Kalimantan Tengah. Sebuah desa yang syarat dengan nilai budaya didukung panorama alam yang asri, udara yang segar dan berbagai flora dan fauna endemik yang masih terjaga, semua hal tersebut dapat anda temukan di sebuah desa yang indah terletak di Kota Palangka Raya Provinsi Kalimantan Tengah.

Desa Wisata Sei Gohong merupakan sebuah desa yang menjadi salah satu tujuan wisata yang cukup populer di Kota Palangka Raya, bagaimana tidak dengan keberadaanya yang cukup dekat dari pusat kota atau hanya berjarak sekitar $35 \mathrm{Km}$ dengan menempuh jalur darat kita langsung bisa mengunjungi destinasi wisata yang satu ini dengan hanya menghabiskan waktu sekitar 20 menit perjalanan.

Sungai Batu yang mengalir indah, bersih, jernih dihiasi bebatuan disepanjang tepian sungai yang membetuk panorama alam yang semakin asri. Air sungai Batu yang berwarna unik merah kehitaman seperti air teh merupakan representative air gambut yang dipercaya memilki khasiat khusus dikarenakan dihasilkan dari berbagai akar-akaran di Bumi Tambun Bungai yang kaya akan khasiat yang terkenal mujarab.

Berkembangnya Sungai Batu Sei Gohong menjadi objek wisata maka akan terbukanya lapangan kerja dan lapangan usaha sehingga membuat masyarakat yang berada di Sei Gohong yang tadinya tidak memiliki pekerjaan dapat terserap melalui industri pariwisata Sungai Batu Sei Gohong. Masyarakat yang berada di sekitar Sungai Batu dapat memperoleh penghasilan dari hasil usaha yang mereka lakukan melalui pengembangan objek wisata yang dilakukan oleh masyarakat maupun pemerintah daerah.

\section{Jurnal Sociopolitico}


Kemudian yang akan diteliti oleh peneliti yaitu kesejahteraan masyarakat sekitar objek wisata yang ikut berpartisipasi dalam memperoleh keuntungan atau menghasilkan pendapatan dari objek wisata Sungai Batu Sei Gohong dan dengan adanya pengembangan objek wisata Sungai Batu Sei Gohong memberikan dampak terhadap kesejahteraan masyarakat yang berada di sekitar objek wisata dan sejauh mana pengaruh pengembangan pariwisata memberikan kesejahtraan bagi penduduk lokal.

\section{Metode Penelitian}

Penelitian ini merupakan jenis penelitian lapangan (Field Research). Penelitian lapangan yaitu suatu penelitian yang dilakukan di lapangan atau di lokasi penelitian, suatu tempat yang dipilih sebagai lokasi untuk menyelidiki gejala objektif yang terjadi di lokasi tersebut. Penelitian lapangan ini akan dilakukan pada objek wisata Sungai Batu Sei Gohong Kecamatan Bukit Batu Kota Palangka Raya.

\section{Hasil dan Pembahasan}

\section{Dampak Pengembangan Pariwisata terhadap Kesejahteraan Masyarakat Pelaku Usaha di Sekitar Sungai Batu Sei Gohong Kota Palangka Raya}

Pembangunan di sektor kepariwisataan perlu ditingkatkan dengan cara mengembangkan dan mendayaguna sumber-sumber serta potensi kepariwisataan nasional maupun daerah, memperluas dan memeratakan kesempatan berusaha dan lapangan pekerjaan terutama bagi masyarakat setempat. Perusahaan atau pengusaha yang beraktivitas pada jasa pariwisata dapat berbentuk usaha kecil, mikro, usaha menengah, maupun usaha besar yang membentuk dan mendukung industri pariwisata.

Adanya objek wisata di Sungai Batu Sei Gohong secara tidak langsung memberi kesempatan peluang pendapatan masyarakat setempat untuk berwirausaha, dan dapat menciptakan peluang kerja khususnya pada masyarakat yang berada di sekitar objek wisata yang belum memiliki pekerjaan. Pengembangan objek wisata Sungai Batu Sei Gohong dikembangkan oleh pemerintah Desa/Kelurahan maupun pemerintah daerah dengan berbagai inovasi dan strategi yang dilakukan.

Berdasarkan hasil wawancara yang dilakukan pada hari Senin 8 Juni 2020 bersama bapak Koharduni selaku pegawai Dinas Pariwisata Kota Palangka Raya. Mengenai usaha dalam pengembangan objek wisata yaitu dengan berbagai macam strategi yang perlu dilakukan yakni melalui 3A, Amenitas (sarana dan prasarana), seperti penyediaan akomodasi, mushola, kotak sampah, listrik, penerangan, kemudian Atraksi (daya tarik wisata) bisa melalui event-event dan Aksebilitas (jalan) melalui perbaikan akses menuju tempat wisata. Ketiga strategi tersebut harus didukung dengan pengembangan Sumber Daya Manusia yang mempunyai keahlian di bidangnya.

Destinasi wisata dapat memberikan dampak bagi masyarakat sekitar seperti meningkatkan pendapatan masyarakat dan daerah jika dikembangkan dengan baik, pengembangan pariwisata berpengaruh positif pada perluasan peluang usaha dan kerja. Peningkatan pendapatan masyarakat dan pemerintah berasal dari pembelanjaan dan biaya yang dikeluarkan wisatawan selama perjalanan dan persinggahannya seperti untuk biaya penginapan, makan dan minum, cindera mata, jasa angkutan dan

\section{Jurnal Sociopolitico}


sebagainya, selain itu mendorong peningkatan dan pertumbuhan dibidang pembangunan sektor lain. Salah satu dari khas pariwisata adalah sifatnya yang tergantung dan terikat dengan bidang pembangunan sektor lainnya. Dengan demikian, berkembangnya kepariwisataan akan mendorong peningkatan dan pertumbuhan bidang pembangunan lainnya.

\section{Analisis Dampak Pengembangan Pariwisata terhadap Kesejahteraan Masyarakat Pelaku Usaha di Sekitar Sungai Batu Sei Gohong Kota Palangka Raya}

Berdasarkan hasil wawancara yang telah dilakukan oleh peneliti, dapat peneliti deskripsikan bahwa dengan berkembangnya objek wisata Sungai Batu Sei Gohong berdampak terhadap kesejahteraan masyarakat pelaku usaha disekitar objek wisata. Kesejahteraan dapat dilihat dengan memperhatikan indikatorindikatornya. Seseorang dapat dikatakan mencapai kesejahteraan jika telah memenuhi beberapa indikator berikut, diantaranya:

1. Jumlah dan Pemerataan Pendapatan Hal ini berkaitan dengan masalah ekonomi, pendapatan berhubungan dengan lapangan kerja, kondisi usaha dan faktor ekonomi lainnya. Kesempatan kerja dan kesempatan usaha diperlukan agar masyarakat pada akhirnya mampu meningkatkan jumlah pendapatan yang diterima dan dengan pendapatan yang mereka terima ini, masyarakat dapat melakukan transaksi ekonomi. Pendapatan warga setempat dalam hari normal yaitu antara $\mathrm{Rp}$. 1.500.000 sampai dengan Rp. 3.000.000 per bulannya. Dengan pendapatan yang mereka terima ini, para pelaku usaha tersebut dapat memenuhi kebutuhan hidup keluarganya. Bahkan jumlah pendapatan yang dihasilkan ketika memiliki sebuah usaha lebih baik bandingkan dengan keadaan atau pekerjaan sebelumnya. Pendapatan yang tinggi ini dapat meningkatkan kesejahteraan pemilik usaha beseta keluarganya.

2. Pendidikan yang semakin mudah dijangkau

Pendidikan yang mudah dan murah merupakan impian semua orang. Dengan pendidikan yang mudah dan murah itu, semua orang dapat dengan mudah mengakses pendidikan setinggitingginya. Dengan pendidikan yang tinggi, kualitas sumberdaya manusia akan semakin meningkat. Kesejahteraan masyarakat dapat dilihat dari kemampuan mereka mengakses pendidikan serta mampu mengunakan pendidikan tersebut unuk melaksanakan kegiatan ekonomi pada sektor riil sebagai usaha pemenuhan kebutuhan hidupnya.

3. Kualitas kesehatan yang semakin meningkat dan merata

Kesehatan merupakan faktor utama untuk mendapatkan pendapatan dan pendidikan. manusia dikatakan sejahtera apabila merasa aman, nyaman dan terhindar dari rasa takut terhadap penindasan, kelaparan, penyakit serta lingkungan.

Berdasarkan pemaparan diatas, masyarakat pelaku usaha di sekitar objek wisata Sungai Batu Sei Gohong dapat disebut cukup sejahtera karena dengan sistem kerja yang tidak terikat oleh jam kerja. Mereka dapat bekerja dengan 
nyaman dan dapat menjaga kesehatan tanpa ada tekanan dari pihak manapun. Selain itu, mereka juga merasa aman tidak lagi takut akan kelaparan dengan penghasilan yang diperoleh setiap bulannya sangat membantu perekonomian keluarganya. Oleh karena itu industri pariwisata sangat penting bagi perekonomian suatu negara, karena dapat membuka lapangan kerja untuk menciptakan pendapatan dan meningkatkan kesejahteraan.

\section{Kesimpulan}

Pengembangan pariwisata Sungai Batu Sei Gohong Kota Palangka Raya memberikan dampak terhadap kesejahteraan masyarakat Sei Gohong yang berada di sekitar objek wisata. Dampak yang signifikan yang dirasakan oleh masyarakat Sei Gohong adalah terbukanya peluang usaha, peluang usaha tersebut terdiri dari usaha kuliner, usaha penginapan, toko cendera mata, toko kelontong, jasa sewa perlengkapan renang. Pendapatan yang diterima oleh masyarakat dari hasil usaha yang dijalankan tersebut dapat mencukupi kebutuhan keluarga, biaya pendidikan dan biaya kesehatan.

\section{Referensi}

Bagus Arjana Gusti, Geografi Pariwisata Dan Ekonomi Kreatif, Jakarta: Rajawali Pers, 2016.

Hermanita, Perekonomian Indonesia, Yogyakarta: Idea Press, 2013.

J Moleong Lexy, Metode Penelitian Kualitatif, Bandung : PT Remaja Rosdakarya, 2009.

Kasiram Moh, Metode Penelitian Kuantitatif-Kualitatif, Yogyakarta,Sukses Offset,2010.
Morissan, Metode Penelitian Survei, Jakarta: Kencana, 2012.

Muljadi, Kepariwisataan Dan Perjalanan, Jakarta:Raja Grafindo, 2010.

Sugiyono, Metode Peneltian Managemen, Bandung: Alfabeta, 2013.

Suharto Edi, Membangun Masyarakat Memberdayakan Rakyat, Bandung: PT Refika Aditama, 2006.

Suwantoro Gamal, Dasar-Dasar Pariwisata, Yogyakarta : Andi Offset, 2004.

Undang-undang No. 11 Tahun 2009 Tentang Kesejahteraan Sosial Undang-Undang Republik Indonesia No.10 Tahun 2009 Tentang Kepariwisataan. Undang-undang Republik Indonesia Nomor 20 tahun 2008 tentang usaha mikro, kecil dan menengah. 